\title{
Influence of Irrigations and Nitrogen Levels on Grain Yield, pH, EC and Available Nutrient Status of White Sorghum at Post Harvest Stage
}

\author{
T. Swami Chaitanya*, P. Munirathnam, P. Kavitha and M. Srinivasa Reddy
}

Department of Agronomy, Agricultural College, Mahanandi, Kurnool, ANGRAU (A.P.), India

*Corresponding author

\section{A B S T R A C T}

\section{Keywords \\ White sorghum, Grain yield, $\mathrm{pH}, \mathrm{EC}$, Available $\mathrm{N}, \mathrm{P}_{2} \mathrm{O}_{5}$ and $\mathrm{K}_{2} \mathrm{O}$ status \\ Article Info \\ Accepted: \\ 10 October 2018 \\ Available Online: \\ 10 November 2018}

Field experiment was conducted at Regional Agricultural Research Station, Nandyal during post rainy season (maghi), 2015-16 to study the response of white sorghum to irrigations and nitrogen levels. The results of the experiment revealed that the available nitrogen status was higher with the application of $180 \mathrm{~kg} \mathrm{~N}^{-1}$ than 150,120 and $90 \mathrm{~kg} \mathrm{~N}$ $\mathrm{ha}^{-1}$ and available phosphorus and available potassium were higher with application of 90 $\mathrm{kg} \mathrm{N} \mathrm{ha-1} \mathrm{than} \mathrm{other} \mathrm{nitrogen} \mathrm{levels.} \mathrm{In} \mathrm{case} \mathrm{of} \mathrm{irrigations,} \mathrm{no} \mathrm{irrigation} \mathrm{recorded} \mathrm{higher}$ available nutrients than two irrigations and one irrigation. Significantly higher grain yield recorded with application of $150 \mathrm{~kg} \mathrm{~N}^{-1}$ than 180,120 and $90 \mathrm{~N} \mathrm{ha}^{-1}$. In case of irrigations the higher grain yield recorded with the two irrigations than one and no irrigation.

\section{Introduction}

Sorghum (Sorghum bicolor (L.) Moench) is the world's fifth major crop in terms of production and acreage. It is a staple food crop for millions of the poorest and most food insecure people in the semi-arid tropics of Africa, Asia and Central America. Sorghum is a highly reliable crop that grows well in hot and dry environments. As the crop is raised mostly under rainfed condition with the help of stored moisture, the moisture deficit, especially during later stages of crop growth poses a serious threat to the crop, consequently the yield levels of rabi sorghum are very low. In Kurnool district, sowings are generally taken up during post rainy season called maghi (middle of September to middle of October). Two situations are prevailing in Kurnool district i.e., in some areas sorghum is completely grown under rainfed conditions whereas in canal ayacut areas, one or two irrigations are being given. Further, under KC canal, it would be very difficult to predict the availability of water for irrigation as the stage of irrigation is very important.

Therefore, it is very important to find out how many irrigations can be provided under limited irrigated conditions under $\mathrm{KC}$ canal ayacut area for enhancing productivity. Farmers generally go for blanket application of nitrogenous fertilizers without actually knowing the requirement of crop particularly if the crop is irrigated. Irrespective of the situation (whether rainfed or irrigated) farmers indiscriminately use nitrogenous fertilizers for 
sorghum. Hence, the present study was conducted to study the effect of irrigations and nitrogen levels on yield and available nutrient status of sorghum during post rainy (maghi) season.

\section{Materials and Methods}

Field experiment was conducted during post rainy season (maghi) 2015-16 at RARS, Nandyal. The experimental soil was clay in texture, and it was moderately alkaline in reaction with a $\mathrm{pH}$ of $8.6, \mathrm{EC}$ of $0.15 \mathrm{dSm}^{-1}$, low in organic carbon $(0.57 \%)$ and low in available nitrogen $\left(146.2 \mathrm{~kg} \mathrm{ha}^{-1}\right)$, medium in available phosphorus $\left(33.2 \mathrm{~kg} \mathrm{ha}^{-1}\right)$ and high in potassium $\left(395.6 \mathrm{~kg} \mathrm{ha}^{-1}\right)$. The experiment was laid out in split plot design with three replications and treatment combinations of three irrigation levels and four nitrogen levels making twelve treatments. The three irrigation levels viz., no irrigation (rainfed), one irrigation and two irrigations and four nitrogen levels viz., 90, 120, 150 and $180 \mathrm{~kg} \mathrm{~N} \mathrm{ha}^{-1}$. Recommended dose of phosphorus $\left(40 \mathrm{~kg} \mathrm{ha}^{-}\right.$ ${ }^{1}$ ) and potassium $\left(30 \mathrm{~kg} \mathrm{ha}^{-1}\right)$ were applied uniformly to all the treatments. Nitrogen was applied in two equal splits. Half of nitrogen along with full dose of phosphorus and potassium was applied as basal at the time of sowing.

The remaining quantity of nitrogen was top dressed at knee-height stage of crop. The grain obtained from the net plot was recorded after a thorough sun drying to obtain a constant weight. The grain yield per hectare was calculated for each individual treatment and expressed in $\mathrm{kg} \mathrm{ha}^{-1}$. Soils samples were collected from each treatment plots at five spots and representative samples were dried and sieved through $2 \mathrm{~mm}$ sieve. The samples were analyzed for $\mathrm{pH}$, EC and available nutrient status using standard procedures as outlined by Jackson (1973). Grain yield was recorded as per the treatments and express in $\mathrm{kg} \mathrm{ha}^{-1}$

\section{Results and Discussion}

\section{Grain yield}

Irrigation levels significantly influenced the grain yield. Application of two irrigations and one irrigation did not bring any significant difference in grain yield, but produced significantly higher grain yields (6101 and $6092 \mathrm{~kg} \mathrm{ha}^{-1}$ ) respectively over no irrigation $\left(2956 \mathrm{~kg} \mathrm{ha}^{-1}\right.$ ) (Table 1). Adequate supply of water under which plant become physiologically more active and also more nutrient availability might have been increased and ultimately resulted in improved growth and development of sink. The similar observations were recorded by Bhuva et al., (2014) in pearlmillet. Application of two supplemental irrigations during critical crop growth cycles gave manifold increase in the grain yield of rabi sorghum (Kadam et al., 2009). Similar increase in yield of rabi sorghum with three irrigations at critical stages was reported by Wani et al., (2003). As explained by Yadav et al., (2014), under irrigated condition, yield increase might be due to increased soil moisture content which improved internal water status and growth of plant. Thus, higher rate of water flow from the soil to plant helps in better stomatal conductance and more leaf area which help to sustain better transpiration thereby improving the ear head numbers, ear head size, thousand grain weight and final grain yield in pearl millet.

Different levels of nitrogen significantly influenced the grain yield of sorghum. Significantly higher grain yield (5486 kg ha-1) was recorded with the application of $150 \mathrm{~kg} \mathrm{~N}$ $\mathrm{ha}^{-1}$ but was comparable with $180 \mathrm{~kg} \mathrm{~N}^{-1}$ (5462 $\mathrm{kg} \mathrm{ha}^{-1}$ ). Application of $90 \mathrm{~kg} \mathrm{~N} \mathrm{ha}^{-1}$ produced significantly lower grain yield (4392 $\left.\mathrm{kg} \mathrm{ha}^{-1}\right)$. Significant improvement in the grain yield was due to marked improvement in yield attributes like number of grains per panicle, 
grain weight per panicle, 1000 grain weight and growth parameters like dry matter production and number of green leaves per plant. These results are in corroboration with Dixit et al., (2005) who reported that increased plant height, leaf-area index, total dry matter accumulation and panicle weight had direct effect on grain yield. Significant increase in grain yield was due to marked improvement in yield contributing characters like grain weight per panicle, 1000 grain weight and growth parameters like dry matter production and number of green leaves per plant (Madhukumar et al., 2013).

The increase in yield of sorghum was due to increase in yield characters like number of grains per panicle, length of ear head and 1000 grain weight with adequate availability of nitrogen, phosphorus and potassium through application of fertilizers (Kushwaha et al., 2007). Significant improvement in grain yield could be ascribed to profound influence of nitrogen fertilization on vegetative and reproductive growth of the crop due to increase in nutrient accumulation and their translocation towards the sink (Patidar and Mali, 2004).

The interaction effect of irrigations and nitrogen levels on grain yield of sorghum was significant. Significantly higher grain yield (6963 $\mathrm{kg} \mathrm{ha}^{-1}$ ) was produced with two irrigations at $180 \mathrm{~kg} \mathrm{~N}^{-1}$ but was on par with two irrigations at $150 \mathrm{~kg} \mathrm{~N} \mathrm{ha}^{-1}(6947 \mathrm{~kg}$ $\left.\mathrm{ha}^{-1}\right)$. On the other hand, lower grain yield $\left(2663 \mathrm{~kg} \mathrm{ha}^{-1}\right)$ was produced with no irrigation at $90 \mathrm{~kg} \mathrm{~N} \mathrm{ha}^{-1}$ which was on par with no irrigation at $120 \mathrm{~kg} \mathrm{~N} \mathrm{ha}^{-1}\left(2943 \mathrm{~kg} \mathrm{ha}^{-1}\right)$ (Table 1a).

\section{pH and EC}

The $\mathrm{pH}$ of soil was not significantly influenced by irrigations and different levels of nitrogen at harvest of sorghum crop. Two irrigations recorded lower $\mathrm{pH}$ (8.12) values than one and no irrigation. With increasing nitrogen fertilizer dose there was a decrease in $\mathrm{pH}$ in all plots after harvest of sorghum crop when compared with initial soil (8.6). Among different nitrogen levels lower $\mathrm{pH}$ values obtained with application of $180 \mathrm{~kg} \mathrm{~N}^{-}$ ${ }^{1}(8.03)$ and it was on par with $150 \mathrm{~kg} \mathrm{~N} \mathrm{ha}^{-1}$ (8.15) but significantly superior over 120 and $90 \mathrm{~kg} \mathrm{~N} \mathrm{ha}{ }^{-1}$. As plant roots absorb ammonium ion they secrete hydrogen ion into the soil solution to maintain a chemical charge balance. As the ammonium- $\mathrm{N}$ in fertilizers undergoes nitrification hydrogen ion released, which increases acidity and it will reduces $\mathrm{p}^{\mathrm{H}}$ (Aula et al., 2016).

Application of two irrigations resulted in lower EC (0.19) compared to one and no irrigation and no irrigation recorded higher EC (0.22) due to accumulation of soluble salts near the soil surface resulting in high EC. Irrigating in amounts too low to leach salts or with water high in salts allows to accumulate in the root zone resulted increasing EC. Clay soils dominated by clay minerals that have a high cation exchange capacity have higher EC than clay soils dominated by clay minerals that have low cation exchange capacity such as kaolinite. Soil EC increased with increasing nitrogen dose but there is no significant difference in between nitrogen levels. Lower EC values obtained with application of $90 \mathrm{~kg}$ $\mathrm{N} \mathrm{ha}^{-1}(0.21)$.

\section{Available nutrient status}

Data on available nitrogen in the soil, after harvest of sorghum, is furnished in Table 1. Post-harvest analysis of soil revealed that the nitrogen status was significantly altered by irrigation levels and levels of nitrogen. Available nitrogen was found to be higher $\left(166.2 \mathrm{~kg} \mathrm{ha}^{-1}\right)$ with no irrigation which was significantly higher than two irrigations and one irrigation. 


\section{Int.J.Curr.Microbiol.App.Sci (2018) 7(11): 1244-1250}

Table.1 Grain yield and soil properties of white sorghum as influenced by different levels of irrigations and Nitrogen at post-harvest stage

\begin{tabular}{|c|c|c|c|c|c|c|}
\hline Treatments & $\begin{array}{l}\text { Grain yield } \\
\left(\mathrm{kg} \mathrm{ha}^{-1}\right)\end{array}$ & pH & $\begin{array}{c}\mathrm{EC} \\
\left(\mathrm{dS} \mathrm{m}^{-1}\right)\end{array}$ & $\begin{array}{c}\text { Available } \mathbf{N} \\
\left(\mathrm{kg} \mathrm{ha}^{-1}\right)\end{array}$ & $\begin{array}{c}\text { Available } \mathrm{P}_{2} \mathrm{O}_{5} \\
\left(\mathrm{~kg} \mathrm{ha}^{-1}\right)\end{array}$ & $\begin{array}{c}\text { A vailable } \mathrm{K}_{2} \mathrm{O} \\
\left(\mathrm{kg} \mathrm{ha}^{-1}\right)\end{array}$ \\
\hline \multicolumn{7}{|c|}{ Irrigations - 3} \\
\hline $\mathrm{I}_{0}$ :No irrigation & 2956 & 8.27 & 0.22 & 166.2 & 28.0 & 220.3 \\
\hline $\mathrm{I}_{1}:$ One irrigation & 6092 & 8.14 & 0.20 & 145.5 & 27.0 & 209.5 \\
\hline $\mathrm{I}_{2}$ :Two irrigations & 6101 & 8.12 & 0.19 & 142.6 & 21.4 & 178.2 \\
\hline SEm \pm & 63 & 0.09 & 0.02 & 4.0 & 0.7 & 8.2 \\
\hline $\mathrm{CD}(\mathrm{P}=0.05)$ & 247 & 0.10 & 0.04 & 15.2 & 3.0 & $32 . .3$ \\
\hline \multicolumn{7}{|c|}{ N-levels $\left(\mathrm{kg} \mathrm{ha}^{-1}\right)-4$} \\
\hline $\mathrm{N}_{1}: 90$ & 4392 & 8.25 & 0.21 & 138.2 & 29.4 & 245.4 \\
\hline $\mathrm{N}_{2}: 120$ & 4858 & 8.17 & 0.22 & 148.3 & 27.4 & 201.0 \\
\hline $\mathrm{N}_{3}: 150$ & 5462 & 8.15 & 0.22 & 156.0 & 23.4 & 187.3 \\
\hline $\mathrm{N}_{4}: 180$ & 5486 & 8.03 & 0.24 & 160.8 & 21.5 & 176.7 \\
\hline SEm \pm & 77 & 0.04 & 0.06 & 5.4 & 1.8 & 5.0 \\
\hline $\mathrm{CD}(\mathrm{P}=\mathbf{0 . 0 5})$ & 228 & 0.12 & 0.02 & 16.1 & 5.4 & 15.0 \\
\hline \multicolumn{7}{|c|}{ I at $\mathbf{N}$} \\
\hline SEm \pm & 127 & 0.12 & 0.04 & 7.8 & 2.8 & 11.2 \\
\hline $\mathrm{CD}(\mathrm{P}=0.05)$ & 425 & N.S & N.S & N.S & N.S & N.S \\
\hline \multicolumn{7}{|l|}{$\mathbf{N}$ at I } \\
\hline $\operatorname{SEm} \pm$ & 131 & 0.18 & 0.17 & 9.0 & 1.5 & 16.5 \\
\hline $\mathrm{CD}(\mathrm{P}=0.05)$ & 420 & N.S & N.S & N.S & N.S & N.S \\
\hline
\end{tabular}


Table.1a Interaction effect of irrigations and nitrogen levels on grain yield $\left(\mathrm{kg} \mathrm{ha}^{-1}\right)$

\begin{tabular}{|c|c|c|c|c|c|}
\hline \multicolumn{1}{|c|}{ Treatments } & \multicolumn{5}{|c|}{ N-levels $\left(\mathrm{kg} \mathrm{ha}^{-1}\right)$} \\
\hline Irrigations & $\mathbf{N}_{\mathbf{1}}: \mathbf{9 0}$ & $\mathbf{N}_{\mathbf{1}}: \mathbf{1 2 0}$ & $\mathbf{N}_{\mathbf{1}}: \mathbf{1 5 0}$ & $\mathbf{N}_{\mathbf{1}}: \mathbf{1 8 0}$ & Mean \\
\hline I0:Noirrigation & 2663 & 2943 & 3090 & 3128 & 2956 \\
\hline I1 : One irrigation & 5637 & 6013 & 6350 & 6367 & 6092 \\
\hline I2: Two irrigations & 4877 & 5617 & 6947 & 6963 & 6101 \\
\hline Mean & 4392 & 4858 & 5462 & 5486 & \\
\hline SEm \pm & & & 127 & \\
\hline CD(P=0.05) & & 425 & \\
\end{tabular}

However, two irrigations $\left(142.6 \mathrm{~kg} \mathrm{ha}^{-1}\right)$ and one irrigation $\left(145.5 \mathrm{~kg} \mathrm{~h}^{-1}\right)$ were on par with each other and recorded significantly lower values for available nitrogen. After harvest of the crop, the soil available nitrogen status was increased with increased levels of nitrogen compared to initial values. The higher soil available nitrogen (160.8 $\left.\mathrm{kg} \mathrm{ha}^{-1}\right)$ was recorded with the highest level of applied nitrogen i.e. $180 \mathrm{~kg} \mathrm{~N} \mathrm{ha}^{-1}$ which was on par with $150 \mathrm{~kg} \mathrm{~N}^{-1}\left(156.0 \mathrm{~kg} \mathrm{ha}^{-1}\right)$ and $120 \mathrm{~kg}$ $\mathrm{N} \quad \mathrm{ha}^{-1}\left(148.3 \mathrm{~kg} \mathrm{ha}^{-1}\right)$ but significantly superior to $90 \mathrm{~kg} \mathrm{~N} \mathrm{ha}^{-1}\left(138.2 \mathrm{~kg} \mathrm{ha}^{-1}\right)$. The increase in post-harvest soil available nitrogen might be due to increased mineralization as a result of increased nitrogen fertilization. Bhanavase et al., (2005) and Bangar et al., (2003) also recorded similar observations.

The interaction between irrigations and nitrogen levels was found to be nonsignificant.

\section{Available phosphorus}

The results pertaining to post harvest soil available phosphorus as influenced by irrigations and different levels of nitrogen are presented in Table 1.

Post-harvest soil available phosphorus was significantly influenced by irrigation levels and different levels of nitrogen but interaction between irrigation levels and nitrogen levels was not significant.
Significantly higher soil available phosphorus was recorded with no irrigation $\left(28.0 \mathrm{~kg} \mathrm{ha}^{-1}\right)$ than two irrigations $\left(21.4 \mathrm{~kg} \mathrm{ha}^{-1}\right)$ but was on par with one irrigation $\left(27.0 \mathrm{~kg} \mathrm{ha}^{-1}\right)$. Higher available nitrogen and phosphorus in the soil with one or no irrigation compared to lower values with irrigation levels might be attributed to non-availability of soil moisture for efficient utilization of applied nutrients.

Therefore, under irrigation treatments the crop might have used applied nitrogen and phosphorus there by leaving less nutrients in the soil.

Regarding the effect of different levels of nitrogen, higher values for soil available phosphorus was associated with the application of $90 \mathrm{~kg} \mathrm{~N} \mathrm{ha}^{-1}\left(29.4 \mathrm{~kg} \mathrm{ha}^{-1}\right)$ which was on par with to $120 \mathrm{~kg} \mathrm{~N} \mathrm{ha}^{-1}(27.4$ $\mathrm{kg} \mathrm{ha}^{-1}$ ) and significantly superior over $150 \mathrm{~kg}$ $\mathrm{N} \mathrm{ha}^{-1}\left(23.4 \mathrm{~kg} \mathrm{ha}^{-1}\right)$ and $180 \mathrm{~kg} \mathrm{~N} \mathrm{ha}^{-1}(21.5$ $\mathrm{kg} \mathrm{ha}^{-1}$ ).

Available phosphorus decreased with increase in nitrogen level. This might be probably due to positive interaction of phosphorus with increased nitrogen application i.e., the acidifying effect of added nitrogen fertilizer which enhance the phosphorus solubility thereby increase the availability of phosphorus to the plants and leaving available phosphorus in the soil after harvest at higher nitrogen levels and vice versa (Sharma and Tandon, 1992). 
The interaction between irrigations and nitrogen levels was found to be nonsignificant.

\section{Available potassium}

Available potassium in the soil after harvest of crop was significantly influenced by both irrigations and nitrogen levels (Table 1). Postharvest soil available potassium was significantly influenced by irrigation levels and different levels of nitrogen but the interaction between irrigation levels and nitrogen levels was found to be nonsignificant. The higher values for available potassium were recorded with no irrigation $220.3 \mathrm{~kg} \mathrm{ha}^{-1}$ which was on par with one irrigation (209.5 $\mathrm{kg} \mathrm{ha}^{-1}$ ) but both were significantly superior over two irrigations $\left(178.2 \mathrm{~kg} \mathrm{ha}^{-1}\right)$.

With regard to levels of nitrogen, significantly higher available soil potassium was associated with the application of $90 \mathrm{~kg} \mathrm{~N}^{-1}(245.4 \mathrm{~kg}$ $\mathrm{ha}^{-1}$ ) which was significantly superior over $120\left(201.0 \mathrm{~kg} \mathrm{ha}^{-1}\right), 150\left(187.3 \mathrm{~kg} \mathrm{ha}^{-1}\right)$ and $180 \mathrm{~kg} \mathrm{~N} \mathrm{ha}{ }^{-1}\left(176.7 \mathrm{~kg} \mathrm{ha}^{-1}\right)$ and the treatments viz., 120,150 and $180 \mathrm{~kg} \mathrm{~N}^{-1}$ remain on par with each other. Potassium also followed the same pattern as that of phosphorus i.e., potassium has positive interaction with nitrogen thereby increased the availability of potassium at crop growth stages and leaving less available potassium after harvest at higher levels of nitrogen.

The interaction between irrigations and nitrogen levels was found to be nonsignificant.

The results were concluded that significantly higher grain yield obatained with application of one irrigation and $150 \mathrm{~kg} \mathrm{~N} \mathrm{ha}{ }^{-1}$. With application of two irrigations recorded lower available nutrients, $\mathrm{pH}$ and $\mathrm{EC}$ values. With increasing nitrogen levels available phosphorus, available potassium and $\mathrm{p}^{\mathrm{H}}$ decreased but available nitrogen and EC values increased. The interaction effect between irrigation and nitrogen levels was found to be non-significant in case of available nutrient status.

\section{References}

Aula, L., Macnack, N., Omra, P., Mullock, J., and Raun, W. 2016. Effect of fertilizer nitrogen $(\mathrm{N})$ on soil organic carbon, Total $\mathrm{N}$ and Soil $\mathrm{P}^{\mathrm{H}}$ in long-term continuous winter wheat (Triticum aestivum L.).Communications in Soil Science and Plant Analysis. 47(7): 863874.

Bangar, A.R., Tamboli, B.D., Kale, K.D., More, N. B and Bhanavase, D. B. 2003. Response of winter sorghum genotypes to nitrogen fertilization under dryland vertisols. Journal of Maharashtra Agricultural University. 28 (2): 211212.

Bhanavase, D. B., Tamboli, B. D., Kale, K. D., More, N. B and Pharande, A. L. 2005. Response of sorghum genotypes to levels of nitrogen in vertisols under dryland condition. Journal of Maharashtra Agricultural University. 30 (2): 144-147

Bhuva, H. M., Sharma, S and Bochalya, B. C. 2014. Cultivar and nitrogen and phosphorus levels influenced on productivity and economics of pearl millet (Pennisetum glaucum L.). Research Journal of Agricultural Sciences. 5(6): 1251-1254.

Dixit, A. K., Singh, O.P., Dileep Kachroo and Amarjit, S., Bali. 2005. Response of promising rainy - season sorghum (Sorghum bicolor) genotypes to nitrogen and phosphorus fertilization. Indian Journal of Agronomy. 50 (3): 206-209. 
Jackson, M. L. 1973. Soil Chemical Analysis. Prentice Hall of India Pvt. Ltd., New Delhi. Pp.134-204.

Kadam, J. R., Thorve, S.B., Upadhye, S. K and Surve, S. P. 2009. Impact of life saving irrigation on yield of rabi sorghum [Sorghum bicolor (L.)]. International Journal of Agricultural Sciences. 5(1): 53-54.

Kushwaha, B. B., Koul, K. K and Vijay Singh. 2007. Performance of Kharif sorghum (Sorghum bicolor L. Moench) under integrated nutrient management system. Indian Journal of Dryland Agricultural Research and Development. 22(1): 32-36.

Madhukumar, M., Munirathnam, $\mathrm{P}$ and Srinivasa Reddy, M. 2013. Studies on the effect of nitrogen fertilization on growth and yield of sorghum (Sorghum bicolor) varieties during post rainy (maghi) season. The Andhra Agricultural Journal. 60 (4): 760-763.
Patidar, M and Mali, A. L. 2004. Effect of farmyard manure, fertility levels and bio-fertilizers on growth, yield and quality of sorghum (Sorghum bicolor). Indian Journal of Agronomy. 49(2):117120.

Sharma, P. K and Tandon, H. L. S. 1992. Nitrogen and phosphorus in crop production. In Management of Nutrient Interactions, Fertilizer Development and Consultation Organization, New Delhi, pp.1-20.

Wani, A. G., Pacharne, D. P and Narkhede, B. N. 2003. Effect of irrigation management on yield of rabi sorghum. Journal of Maharashtra Agricltural University. 28(2):157-158.

Yadav, A. K., Anil Kumar, Jagdev Singh, Jat, R. D., Jat, H. S., Ashim Datta, Kuldeep Singh and Rakesh Chaudhary.2014. Performance of pearl millet genotypes under irrigated and rainfed conditions at Hisar, India. Journal of Applied and Natural Science. 6(2): 377-382.

\section{How to cite this article:}

Swami Chaitanya, T., P. Munirathnam, P. Kavitha and Srinivasa Reddy, M. 2018. Influence of Irrigations and Nitrogen Levels on Grain Yield, $\mathrm{pH}, \mathrm{EC}$ and Available Nutrient Status of White Sorghum at Post Harvest Stage. Int.J.Curr.Microbiol.App.Sci. 7(11): 1244-1250. doi: https://doi.org/10.20546/ijcmas.2018.711.145 